\title{
PENGARUH MODEL PEMBELAJARAN DISKUSI KELAS DENGAN METODE SEMINAR SOCRATES TERHADAP HASIL BELAJAR SISWA MATERI KALOR KELAS X SMA NEGERI 8 MEDAN T.P 2013/2014
}

\author{
Meutia Kemala Putri dan Ridwan Abdullah Sani \\ mutmutkemala@yahoo.com \\ Jurusan Fisika FMIPA Universitas Negeri Medan \\ Jalan Willem Iskandar Pasar V Medan, 20221
}

\begin{abstract}
This study aims to determine the effect of classroom discussion learning model using Socratic seminar method to the student's learning result in the heat topic of second semester X Class of SMA Negeri 8 Medan T.P 2013/2014. This research is quasi experimental with research design is Two Group Pretes-Postes Design. The population in this research was all students in class X which consists of 12 classes and the totaled is 343 students. Class $\mathrm{X}-8$ and $\mathrm{X}-7$ were chosen as an experimental class and control class with random sampling technique. Instrument learning results were contain of multiple-choice tests and observation sheet of student activity in the classroom. Average data of pre-test experimental class and control class are 44,33 and 40,33. In both classes, the pretest data are normally distributed and homogeneous. The ability of students at the beginning of both classes are same as analyzed by t-test. After treatment, the data of learning achievement using posttest, shows average yield of experimental class and control class are 70,17 and 56,50, which are normally distributed and homogeneous. Based on t-test, $\mathrm{H}_{\mathrm{a}}$ was accepted and reveal that there is significant influence of classroom discussion learning model using Socratic Seminar method to the student learning outcomes.
\end{abstract}

Keywords : classroom discussion, Socratic seminar, quasi experiment, learning results

\section{PENDAHULUAN}

Pendidikan memegang peranan penting bagi kelangsungan kehidupan manusia. Berawal dari kesuksesan di bidang pendidikan suatu bangsa menjadi maju. Melalui pendidikan diharapkan dapat menghasilkan sumber daya manusia yang berkualitas dan mampu menjawab tantangan zaman yang pada akhirnya dapat mewujudkan kemajuan bangsa. Kualitas sumber daya manusia Indonesia masih dalam kategori sedang (medium) dibandingkan negara-negara lain di dunia. Berdasarkan catatan Human Development Report tahun 2012 versi UNDP bahwa peringkat Human Development Indeks atau Indeks Pembangunan Manusia Indonesia berada di urutan 121 dari 187 negara. Peringkat ini masih jauh tertinggal di bawah negara-negara tetangga seperti Jepang (10), 
Singapura (18), Brunei Darussalam (30), Malaysia (64), Thailand (103) dan sebagainya (UNDP, 2012).

Berdasarkan Peraturan Menteri Pendidikan dan Kebudayaan Nomor 69 tahun 2013 tentang kerangka dasar dan struktur kurikulum Sekolah Menengah Atas/Madrasah Aliyah, saat ini jumlah penduduk Indonesia usia produktif (15-64 tahun) lebih banyak dari usia tidak produktif (anak-anak berusia 0-14 tahun dan orang tua berusia $>65$ tahun). Tantangan besar yang dihadapi adalah bagaimana mengupayakan agar sumber daya manusia usia produktif yang melimpah ini dapat ditransformasikan menjadi sumber daya manusia yang memiliki kompetensi dan keterampilan melalui pendidikan agar tidak menjadi beban. Hal tersebut pulalah yang menjadi salah satu faktor mengapa kurikulum 2013 dikembangkan.

Proses pembelajaran pada satuan pendidikan seharusnya diselenggarakan secara interaktif, inspiratif, menyenangkan, menantang, memotivasi peserta didik untuk berpartisipasi aktif, serta memberikan ruang yang cukup bagi prakarsa, kreativitas dan kemandirian sesuai dengan bakat, minat dan perkembangan fisik serta psikologis peserta didik. Proses pembelajaran kurikulum 2013, menekankan penerapan pendekatan scientific (ilmiah), yang mana pendekatan tersebut sangat sesuai digunakan untuk pembelajaran sains, terutama pelajaran fisika.

Berdasarkan hasil observasi peneliti sebanyak 2 (dua) kali di SMA Negeri 8 Medan didapat beberapa kendala yang dihadapi dalam proses pembelajaran, yaitu: (1) Siswa kurang aktif dan aktifitas belajar bersifat pasif; (2) Siswa selalu menantikan jawaban yang tepat dari siswa yang pintar dan jarang mengajukan pertanyaan; (3) Siswa masih merasa tidak percaya diri untuk mengemukakan pendapat dan memberikan tanggapan terhadap pendapat teman sekelasnya; (4) Siswa menganggap guru sebagai narasumber yang paling tepat dalam menyelesaikan tugas; (5) Siswa tidak biasa melakukan praktikum (eksperimen) dalam pembelajaran.

Permasalahan lain yang ditemukan adalah rendahnya hasil belajar siswa terutama pada mata pelajaran fisika. Berdasarkan hasil wawancara dengan salah seorang guru di SMA Negeri 8 Medan mengatakan hasil belajar siswa masih rendah. Kriteria Ketuntasan Minimal (KKM) untuk pelajaran fisika di SMAN 8 Medan adalah 70. Namun hanya $50 \%$ siswa yang mencapai KKM, yaitu memiliki nilai $\geq 70, \quad$ sedangkan $\quad 50 \% \quad$ siswa selebihnya memiliki nilai $<70$.

Aktifitas pembelajaran fisika yang terjadi di kelas X SMA Negeri 8 minim dengan diskusi dan tanya jawab. Siswa cenderung pasif dalam pembelajaran. Hanya siswa yang pintar saja yang aktif melakukan tanya jawab kepada guru. Padahal seharusnya, dalam pendekatan ilmiah seluruh siswa dituntut untuk aktif mengamati, menanya, menalar, mencoba dan membentuk jejaring untuk semua mata pelajaran.

Berdasarkan masalah yang dikemukakan di atas maka perlu dikembangkan model pembelajaran yang dapat meningkatkan hasil belajar siswa melalui diskusi. Melalui diskusi dengan tanya jawab 
yang terjadi baik antara siswa-siswa ataupun siswa-guru, siswa didorong untuk mengembangkan kemampuan berfikirnya, kemudian siswa dapat memahami informasi yang diperolehnya dan menghubungkan dengan kehidupan sehari-hari.

Diskusi merupakan titik sentral dalam semua aspek pembelajaran. Atas alasan demikian diksusi kelas merupakan salah satu bagian penting dalam suatu proses pembelajaran. Dengan kata lain, interaksi antara guru-siswa, siswasiswa dalam proses pembelajaran sangat ditentukan oleh bagaimana proses diskusi kelas dioptimalisasi. Dengan diskusi kelas ini guru dapat mengubah beberapa pola komunikasi yang tidak produktif yang menjadi ciri kebanyakan kelas pada saat ini (Trianto, 2009:121).

Adapun fase-fase dalam diskusi kelas yaitu (Arends, 2008):

Tabel 1. Sintaks Pembelajaran Model Diskusi Kelas

\begin{tabular}{|c|l|}
\hline \multicolumn{1}{|c|}{ FASE-FASE } & PERILAKU GURU \\
\hline \multicolumn{1}{|c|}{ Fase 1 } & Guru membahas \\
Mengklarifikasikan & maksud diskusi \\
maksud dan & dan \\
establishing set & mempersiapkan \\
(mengatur siswa) & siswa untuk \\
& berpartisipasi \\
\hline \multicolumn{1}{|c|}{ Fase 2 } & Guru memberikan \\
Memfokuskan & fokus untuk \\
diskusi & diskusi dengan \\
& mendeskripsikan \\
& peraturan \\
& dasarnya, \\
& mengajukan \\
& pertanyaan awal, \\
& menyodorkan \\
& situasi yang \\
& membingungkan, \\
& atau \\
& mendeskripsikan \\
& sebuah isu diskusi \\
\hline
\end{tabular}

\begin{tabular}{|c|l|}
\hline \multicolumn{1}{|c|}{ Fase 3 } & Guru memantau \\
diskusi & interaksi siswa, \\
melontarkan & pertanyaan, \\
& mendengarkan \\
ide-ide, merespon \\
ide-ide, \\
& menegakkan \\
& peraturan \\
dasarnya, \\
& mencatat proses \\
diskusi, dan \\
& mengekspresikan \\
& ide-idenya sendiri \\
\hline Fase 4 & Guru membantu \\
mengakhiri \\
Mengakhiri diskusi & diksusi dengan \\
& merangkum atau \\
& mengekspresikan \\
& makna diskusi \\
& bagi dirinya \\
\hline Fase 5 & Guru \\
memerintahkan \\
Debriefing (tanya \\
jawab/wawancara) & menelaah \\
& diskusinya dan \\
& memikirkan \\
proses-prosesnya \\
\hline
\end{tabular}

Secara khusus, menurut Arends (2008) dengan menggunakan model diskusi kelas dapat dicapai (3) tiga tujuan pembelajaran yang penting oleh guru. Pertama, diskusi meningkatkan kemampuan berpikir siswa dan membantu mereka mengonstruksikan pemahamannya sendiri tentang isi akademik. Mendiskusikan sebuah topik membantu memperkuat, memperluas pengetahuan siswa tentang topik itu dan meningkatkan kemampuannya untuk memikirkan tentang hal itu. Kedua, diskusi meningkatkan keterlibatan dan engangement (keterkaitan) siswa. Diskusi memberikan kesempatan kepada siswa untuk berbicara dan memainkan ide-idenya sendiri di depan umum dan memberikan 
motivasi untuk terlibat di dalam wacana di luar kelas. Ketiga, diskusi digunakan oleh guru untuk membantu siswa mempelajari berbagai keterampilan komunikasi dan proses berpikir yang penting, seperti menyatakan ide-ide dengan jelas, mendengarkan orang lain, merespons orang lain dengan cara yang baik, dan mengajukan pertanyaan yang baik.

Penggunaan model diskusi kelas dapat meningkatkan keaktifan siswa dalam proses belajar. Variasi metode perlu diterapkan agar siswa tidak jenuh dengan pembelajaran yang diberikan. Metode seminar Socrates dapat meningkatkan dan mengembangkan kemampuan bertanya (mengajukan pertanyaan dan atau pernyataan) siswa, dimana bertanya merupakan salah satu langkah pendekatan pembelajaran ilmiah (Sani, 2013).

Tujuan dari penelitian ini adalah mengetahui hasil belajar siswa dengan menggunakan model pembelajaran diskusi kelas dengan metode seminar Socrates dan pembelajaran konvensional, mengetahui aktivitas siswa pada kelas eksperimen dan kelas kontrol dan mengetahui perbedaan akibat pengaruh model pembelajaran diskusi kelas dengan seminar Socrates.

\section{METODE PENELITIAN}

Penelitian ini dilaksanakan di SMA Negeri 8 Medan pada semester genap, tahun pembelajaran 2013/2014 beralamat di Jalan Sampali No. 23 Medan.

Populasi dalam penelitian ini adalah seluruh siswa kelas X SMA N 8 Medan yang, terdiri dari 12 kelas, yang seluruhnya berjumlah 343 siswa.

Sampel penelitian ditentukan dengan teknik random sampling untuk memperoleh dua kelas yang masing-masing merupakan kelas eksperimen (pembelajaran menggunakan model pembelajaran diskusi kelas dengan metode seminar Socrates) dan kelas kontrol (pembelajaran menggunakan pembelajaran konvensional). Diperoleh kelas X-8 sebagai kelas eksperimen yang berjumlah 30 siswa dan kelas X-7 sebagai kelas kontrol berjumlah 30 siswa.

Instrumen yang digunakan adalah tes hasil belajar siswa dan observasi aktivitas siswa. Tes hasil belajar siswa berjumlah 20 soal dalam bentuk pilihan berganda dengan 4 option yaitu a, b, c dan d. Tes ini diberikan sebanyak 2 kali yaitu saat pretes dan postes. Sedangkan observasi yang dimaksud dalam penelitian ini adalah mengadakan pencatatan secara sistematis menganai tingkah laku dengan mengamati individu secara langsung dan dilakukan oleh pengamat (Sugiyono,2010). Observasi yang dilakukan untuk mengamati keseluruhan aktivitas belajar siswa selama pembelajaran.

Penelitian ini melibatkan dua kelas yang diberi perlakuan yang berbeda. Kelas eksperimen diajarkan dengan menggunakan model pembelajaran diskusi kelas dengan metode seminar Socrates dan kelas kontrol dengan pembelajaran konvensional. Untuk mengetahui hasil belajar fisika siswa dilakukan dengan memberikan tes pada kedua kelas sebelum dan sesudah diberikan perlakuan. Rancangan penelitian ini ditunjukkan pada Tabel 2 . 
Tabel 2. Two Group PretestPosttest Design

\begin{tabular}{|l|c|c|c|}
\hline \multicolumn{1}{|c|}{ Kelas } & Pretes & Perlakuan & Postes \\
\hline Eksperimen & $\mathrm{T}_{1}$ & $\mathrm{X}_{1}$ & $\mathrm{~T}_{2}$ \\
\hline Kontrol & $\mathrm{T}_{1}$ & $\mathrm{X}_{2}$ & $\mathrm{~T}_{2}$ \\
\hline
\end{tabular}

Dengan: $\begin{array}{rr}\mathrm{X}_{1}=\begin{array}{rr}\text { Pembelajaran } \\ \text { menggunakan } \\ \text { pembelajaran }\end{array} & \text { diskusi } \\ & \text { model } \\ & \text { kelas }\end{array}$ dengan metode seminar Socrates

$\mathrm{X}_{2}=$ Pembelajaran menggunakan pembelajaran konvensional

$\mathrm{T}_{1}=$ Pretes diberikan kepada kelas eksperimen dan kelas kontrol sebelum perlakuan

$\mathrm{T}_{2}=$ Postes diberikan setelah perlakuan pada kelas eksperimen dan kelas kontrol

Penelitian diawali dengan memberikan pretes terhadap kedua sampel yang bertujuan untuk mengetahui kemampuan awal belajar siswa pada masing-masing kelas. Selanjutnya dilakukan uji normalitas pada hasil pretes untuk menentukan apakah data berdistribusi normal, uji homogenitas apakah sampel yang dipakai dapat mewakili seluruh populasi yang ada dan uji t untuk menentukan apakah ada perbedaan yang signifikan antara hasil belajar kelas eksperimen dan kelas kontrol. Selanjutnya kedua kelas diberi perlakuan yang berbeda. Kelas eksperimen diajarkan dengan model pembelajaran diskusi kelas dengan metode seminar Socrates, dan kelas kontrol dengan pembelajaran konvensional. Setelah itu kedua kelas diberi postes. Berdasarkan hasil postes yang diperoleh dilakukan kembali uji normalitas (menentukan apakah data berdistribusi normal), homogenitas (apakah sampel yang dipakai mewakili seluruh populasi yang ada) dan uji t (untuk menentukan apakah ada perbedaan yang signifikan antara hasil belajar kedua kelas) (Sudjana, 2005).

\section{HASIL DAN PEMBAHASAN}

a. Hasil Penelitian

Data hasil penelitian ini berupa hasil belajar siswa pada pretes dan postes dan hasil observasi.

Penelitian diawali dengan memberikan pretes terhadap kedua sampel yang bertujuan untuk mengetahui kemampuan awal belajar siswa pada masing-masing kelas. Hasil pretes kelas eksperimen memperoleh nilai rata-rata 44,33 dan nilai rata-rata kelas kontrol adalah 40,33. Secara ringkas hasil pretes kedua kelas ditunjukkan pada Tabel 3 .

Tabel 3. Data Pretes Kelas Eksperimen dan Kelas Kontrol

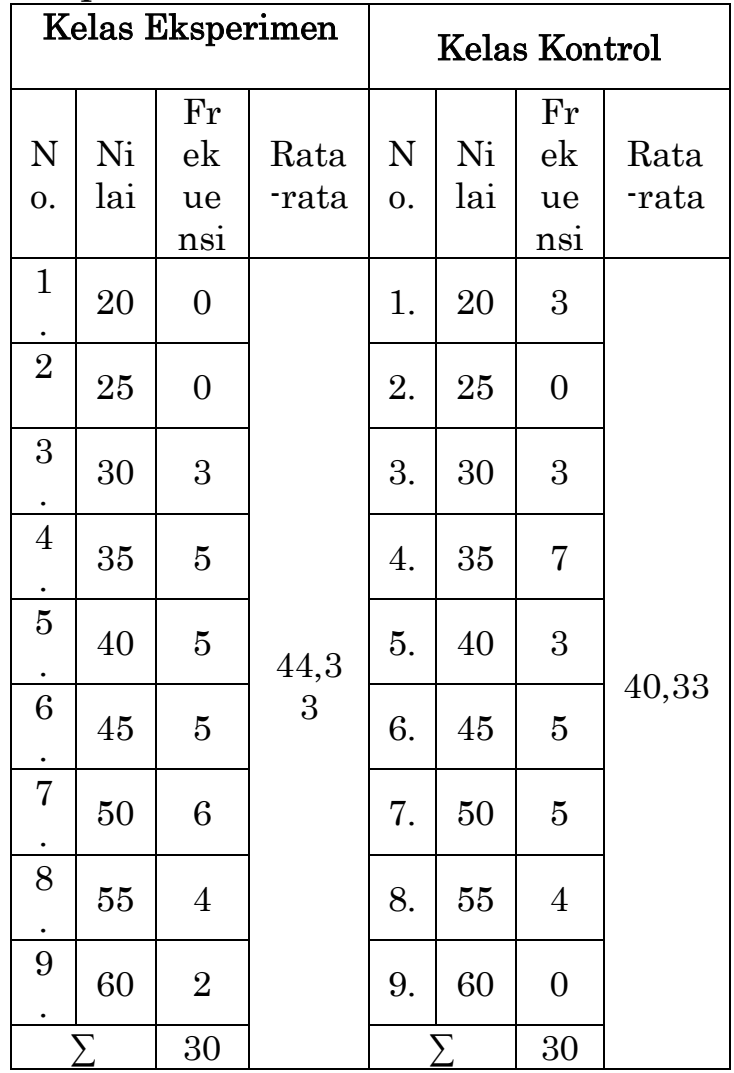


Berdasarkan uji t ternyata hasil tersebut menyatakan bahwa kemampuan awal siswa pada kelas eksperimen sama dengan kemampuan awal siswa pada kelas kontrol dan dengan menggunakan uji F (varians) diperoleh bahwa kedua kelas homogen.

Setelah diberi perlakuan, kedua kelas selanjutnya diberikan postes dengan soal yang sama dengan pretes. Hasil yang diperoleh adalah nilai rata-rata postes kelas eksperimen dan kelas kontrol adalah 70,17 dan 56,50. Secara ringkas hasil postes kedua kelas ditunjukkan pada Tabel 4.

Tabel 4. Data Postes Kelas Eksperimen dan Kelas Kontrol

\begin{tabular}{|c|c|c|c|c|c|c|c|}
\hline \multicolumn{4}{|c|}{ Kelas Eksperimen } & \multicolumn{4}{|c|}{ Kelas Kontrol } \\
\hline No. & $\begin{array}{c}\mathrm{Ni} \\
\text { la } \\
\mathrm{i}\end{array}$ & $\begin{array}{l}\text { Fre } \\
\text { kue } \\
\text { nsi }\end{array}$ & $\begin{array}{l}\text { Rata } \\
\text {-rata }\end{array}$ & $\begin{array}{c}\text { No } \\
\text {. }\end{array}$ & $\begin{array}{l}\mathrm{N} \\
\text { il } \\
\text { ai }\end{array}$ & $\begin{array}{l}\mathrm{Fr} \\
\text { ek } \\
\text { ue } \\
\text { nsi }\end{array}$ & $\begin{array}{l}\text { Rata- } \\
\text { rata }\end{array}$ \\
\hline 1. & 35 & 0 & \multirow{13}{*}{$\begin{array}{c}70,1 \\
7\end{array}$} & 1. & $\begin{array}{l}3 \\
5\end{array}$ & 1 & \multirow{13}{*}{56,50} \\
\hline 2. & 40 & 1 & & 2. & $\begin{array}{l}4 \\
0\end{array}$ & 2 & \\
\hline 3. & 45 & 0 & & 3. & $\begin{array}{l}4 \\
5\end{array}$ & 0 & \\
\hline 4. & 50 & 1 & & 4. & $\begin{array}{l}5 \\
0\end{array}$ & 3 & \\
\hline 5. & 55 & 1 & & 5. & $\begin{array}{l}5 \\
5\end{array}$ & 7 & \\
\hline 6. & 60 & 5 & & 6. & $\begin{array}{l}6 \\
0\end{array}$ & 4 & \\
\hline 7. & 65 & 6 & & 7. & $\begin{array}{l}6 \\
5\end{array}$ & 5 & \\
\hline 8. & 70 & 7 & & 8. & $\begin{array}{l}7 \\
0\end{array}$ & 5 & \\
\hline 9. & 75 & 3 & & 9. & $\begin{array}{l}7 \\
5\end{array}$ & 3 & \\
\hline 10. & 80 & 5 & & 10. & $\begin{array}{l}8 \\
0\end{array}$ & 3 & \\
\hline 11. & 85 & 4 & & 11. & $\begin{array}{l}8 \\
5\end{array}$ & 2 & \\
\hline 12. & 90 & 2 & & 12. & $\begin{array}{l}9 \\
0\end{array}$ & 0 & \\
\hline$\sum$ & & 30 & & 2 & & 30 & \\
\hline
\end{tabular}

Berdasarkan Tabel 4 dapat dilihat hasil rata-rata postes kelas eksperimen dan kelas kontrol bahwa nilai yang dicapai kelas eksperimen lebih baik dari kelas kontrol. Hasil uji normalitas untuk kedua sampel menunjukkan bahwa kedua kelas berdistribusi normal dimana $\mathrm{L}_{\text {hitung }}<$ $\mathrm{L}_{\text {tabel }}$ dan berasal dari populasi yang homogen. Hasil uji hipotesis untuk postes menggunakan uji t pada taraf signifikan $\alpha=0,05$ diperoleh $t_{\text {hitung }}>$ $t_{\text {tabel }}(4,79 \quad>1,982)$ yang berarti bahwa ada pengaruh yang signifikan akibat pengaruh model pembelajaran diskusi kelas dengan metode seminar Socrates terhadap hasil belajar siswa.

Aktivitas belajar siswa selama pembelajaran dilakukan dengan cara observasi yang diamati oleh observer. Observasi dilakukan selama pembelajaran selama tiga kali pertemuan. Aspek aktivitas belajar siswa yang diamati meliputi mengamati, menanya, mengumpulkan informasi, mengolah informasi dan mengkomunikasikan. Hasil aktivitas belajar siswa pada kelas eksperimen dan kelas kontrol ditunjukkan pada Tabel 5 dan Tabel 6.

Tabel 5. Aktivitas Siswa Kelas Eksperimen

\begin{tabular}{|c|c|c|c|c|c|}
\cline { 2 - 6 } \multicolumn{1}{c|}{} & \multicolumn{5}{c|}{ Aktivitas Siswa } \\
\hline $\begin{array}{l}\text { Per } \\
\text { te } \\
\text { mu } \\
\text { an } \\
\text { Ke }\end{array}$ & $\begin{array}{c}\text { Meng } \\
\text { amati }\end{array}$ & $\begin{array}{c}\text { Men } \\
\text { anya }\end{array}$ & $\begin{array}{c}\text { Mengum } \\
\text { pulkan } \\
\text { Informas } \\
\text { i }\end{array}$ & $\begin{array}{c}\text { Meng } \\
\text { olah } \\
\text { Infor } \\
\text { masi }\end{array}$ & $\begin{array}{c}\text { Meng } \\
\text { komu } \\
\text { nikas } \\
\text { ikan }\end{array}$ \\
\hline I & 44,44 & $\begin{array}{c}41,1 \\
1\end{array}$ & 45,56 & 43,33 & 37,78 \\
\hline II & 68,89 & $\begin{array}{c}55,5 \\
6\end{array}$ & 66,67 & 65,56 & 56,67 \\
\hline III & 93,33 & $\begin{array}{c}71,1 \\
1\end{array}$ & 86,67 & 80 & 70 \\
\hline
\end{tabular}


Tabel 6. Aktivitas Siswa Kelas Kontrol

\begin{tabular}{|c|c|c|c|c|c|}
\cline { 2 - 6 } \multicolumn{1}{c|}{} & \multicolumn{5}{c|}{ Aktivitas Siswa } \\
\hline $\begin{array}{l}\text { Per } \\
\text { te } \\
\text { mu } \\
\text { an } \\
\text { Ke- }\end{array}$ & $\begin{array}{c}\text { Men } \\
\text { g } \\
\text { amat } \\
\text { i }\end{array}$ & $\begin{array}{c}\text { Men } \\
\text { a } \\
\text { nya }\end{array}$ & $\begin{array}{c}\text { Mengum } \\
\text { pulkan } \\
\text { Informas } \\
\text { i }\end{array}$ & $\begin{array}{c}\text { Meng } \\
\text { olah } \\
\text { Infor } \\
\text { masi }\end{array}$ & $\begin{array}{c}\text { Meng } \\
\text { komu } \\
\text { nikas } \\
\text { ikan }\end{array}$ \\
\hline I & $\begin{array}{c}33,3 \\
3\end{array}$ & $\begin{array}{c}33,3 \\
3\end{array}$ & 33,33 & 33,33 & 33,33 \\
\hline II & $\begin{array}{c}47,7 \\
8\end{array}$ & $\begin{array}{c}33,3 \\
3\end{array}$ & 42,22 & 44,44 & 35,56 \\
\hline III & $\begin{array}{c}50,0 \\
0\end{array}$ & $\begin{array}{c}38,8 \\
9\end{array}$ & 43,33 & 44,44 & 37,78 \\
\hline
\end{tabular}

Berdasarkan Tabel 5 dan Tabel 6 dapat dilihat bahwa rata-rata nilai aktivitas belajar siswa di kelas eksperimen lebih tinggi daripada kelas kontrol di setiap pertemuan. Kelas eksperimen dengan kategori aktif dan kelas kontrol dengan kategori kurang aktif.

\section{b. Pembahasan Penelitian}

Adanya pengaruh model pembelajaran diskusi kelas dengan metode seminar Socrates terhadap hasil belajar siswa disebabkan oleh kelebihan model pembelajaran diskusi kelas yaitu menekankan siswa untuk mengkonstruksikan pemahamannya sendiri tentang materi yang dipelajari dan terlibat secara aktif dalam diskusi dan dapat mengkomunikasikan ide-idenya kepada lingkungannya. Berbeda dengan pembelajaran konvensional yang ada di sekolah SMA N 8 Medan yang didominasi metode ceramah oleh guru yang membuat pembelajaran berpusat pada guru yang menyebabkan siswa menjadi kurang aktif. Hanya siswa yang lebih pintar saja yang aktif berinteraksi saat pembelajaran. Pada pembelajaran konvensional juga siswa tidak terbiasa melakukan praktikum (metode eskperimen). Guru biasanya hanya sesekali melakukan demonstrasi di depan kelas, yang membuat siswa tidak bisa mengamati percobaan secara langsung dan terkadang tidak semua siswa dapat melihat demonstrasi yang dilakukan guru karena keterbatasan ruang bagi guru untuk mendemonstrasikannya

Keterampilan siswa yang dikembangkan dalam pembelajaran dengan menggunakan model pembelajaran diskusi kelas dengan metode seminar Socrates adalah keterampilan berpikir dan keterampilan berkomunikasi. Hal ini didukung oleh pendapat Trianto (2009) yang menyatakan bahwa dengan model pembelajaran diskusi kelas guru dapat mengubah beberapa pola komunikasi yang tidak produktif yang menjadi ciri kebanyakan kelas pada saat ini. Dan didukung pula oleh pendapat Arends (2008), bahwa dengan diskusi kelas guru dapat mencapai paling tidak tiga tujuan instruksional penting dalam pembelajaran yaitu: pembelajaran ini meningkatkan kemampuan berpikir siswa dan membantu siswa mengonstruksikan, (2) memberikan kesempatan kepada siswa untuk berbicara dan memainkan ide-idenya sendiri di depan umum dan memberikan motivasi untuk terlibat di dalam wacana di luar kelas, (3) model ini membantu siswa melatih keterampilan komunikasi dan proses berpikir yang penting seperti menyatakan ide-ide dengan jelas, mendengarkan orang lain, merespons orang lain dengan cara yang baik dan mengajukan pertanyaan dengan baik.

Awal dari tahap ini peneliti memberikan penjelasan kepada siswa tujuan yang harus dicapai baik 
tujuan yang berhubungan dengan penguasaan materi pelajaran yang harus dicapai, maupun tujuan yang berhubungan dengan proses pembelajaran serta memotivasi siswa agar lebih aktif dalam belajar, yang merupakan kegiatan dalam fase "Megklarifikasikan maksud dan establishing set'. Akan sulit bagi siswa untuk melaksanakan suatu tugas dengan baik apabila belum mengetahui jelas tentang apa dan mengapa melakukan suatu kegiatan atau apabila kriteria keberhasilan belum diberitahukan secara terbuka. Pada saat menyajikan materi, peneliti memberikan pertanyaan yang dihubungkan langsung dengan kehidupan nyata yang membuat siswa tertarik untuk segera mencari jawaban dari permasalahan tersebut. Pertanyaan ini disamping untuk mengetahui kemampuan dasar siswa juga untuk mengarahkan siswa berpikir kreatif. Kemudian pada fase kedua, "Memfokuskan Diskusi", peneliti mengarahkan siswa untuk membentuk kelompok yang terdiri dari 6 orang dan berjumlah 5 kelompok. Kemudian peneliti membagi LKS untuk setiap siswa dan membagikan seperangkat alat percobaan untuk masing-masing kelompok yang membuat siswa tertarik melakukan praktikum, karena siswa berinteraksi langsung dengan alat percobaan, berbeda dengan pembelajaran konvensional yang hanya dilakukan demonstrasi oleh guru. Peneliti terlebih dahulu menjelaskan prosedur praktikum sebelum siswa melakukan kegiatan tersebut agar siswa lebih paham melakukan praktikum sesuai dengan prosedur pada LKS. Kemudian siswa mulai melakukan praktikum secara kelompok untuk mengumpulkan dan mengolah data. Lalu setelah mendapatkan informasi dari praktikum, peneliti akan meminta siswa untuk mengkomunikasikan data yang didapatnya dalam diskusi kelas dengan seminar Socrates pada fase yang ketiga yaitu "Mengendalikan Diskusi". Pada fase ini, siswa akan dibentuk menjadi dua kelompok yaitu kelompok lingkaran dalam dan kelompok luar sesuai dengan aturan duduk pada metode seminar Socrates. Kemudian peneliti akan melontarkan pertanyaan divergen (terbuka) yang memancing siswa untuk mengekspresikan ideidenya berdasarkan informasi yang telah didapatnya dari melakukan praktikum. Pada fase ini peneliti memantau interaksi siswa dan mencatat proses diskusi, serta menegakkan peraturan diskusi agar diskusi terkendali dengan baik, diantaranya aturan bahwa siswa dilarang untuk melakukan interupsi ketika ada yang berbicara pada saat diskusi berlangsung. Pada fase inilah, keterampilan komunikasi siswa dilatih. Dengan berdiskusi, siswa dapat menyatakan pendapatnya dengan jelas, mendengarkan orang lain, merespons orang lain dengan cara yang baik, dan mengajukan pertanyaan dengan baik. Kemudian pada fase keempat, "Mengakhiri Diskusi", peneliti membantu siswa mengakhiri diskusi dengan merangkum makna diskusi dari pembelajaran pada pertemuan tersebut. Lalu lanjut pada fase terakhir, fase kelima, yaitu fase "Debriefing" dimana pada fase inilah siswa dituntut untuk menelaah diskusinya dan memikirkan kembali proses-proses diskusi pada pertemuan tersebut. Pada fase ini 
siswa diberikan kesempatan untuk bertanya lebih mendalam kepada guru (peneliti) tentang hal-hal yang masih belum dipahami oleh siswa. Lalu pada akhir pertemuan, siswa diberikan tugas yang berkaitan dengan materi pada pertemuan saat itu agar lebih memahami materi yang telah dipelajari.

Selama kegiatan pembelajaran yang terdiri dari tiga kali pertemuan berlangsung, observer mengamati dan mencatat perkembangan aktivitas siswa. Berdasarkan perolehan data nilai rata- rata aktivitas, antara kelas eksperimen dan kelas kontrol mengalami peningkatan nilai rata-rata di setiap pertemuannya walaupun sangat berbeda, yaitu kelas eksperimen pada kategori aktif dan kelas kontrol pada kategori kurang aktif. Karena pada kelas ekperimen menggunakan metode eksperimen yang dapat membuat pengetahuan dibangun oleh siswa sendiri secara aktif dapat melalui proses personal maupun sosial. Peningkatan aktivitas yang paling tinggi ada pada aspek mengamati. Hal ini terjadi karena model diskusi kelas dapat memberikan kesempatan kepada siswa berpartisipasi aktif pada pembelajaran. Melalui eksperimen, siswa dapat mengaktifkan indranya untuk memperoleh pemahaman dan siswa dapat membangun sendiri pengetahuan mereka melalui keterlibatan aktif dalam proses belajar dan mengajar.

Hasil penelitian menunjukkan penggunaan model pembelajaran diskusi kelas dengan metode seminar Socrates dapat memberikan pengaruh yang signifikan pada hasil belajar dan aktivitas siswa, namun dalam pembelajaran masih ada kendala yang dihadapi. Diantaranya pada fase kedua "Memfokuskan Diskusi", saat melakukan praktikum, dikarenakan kurang terbiasanya siswa menggunakan metode eksperimen, mengakibatkan peneliti memerlukan banyak waktu dalam membimbing pelaksanaan praktikum tersebut. Kemudian kendala lainnya karena siswa jarang melakukan pembelajaran dalam bentuk kelompok membuat siswa membutuhkan waktu yang cukup lama untuk bergabung dengan kelompok-kelompoknya.

Dibutuhkannya waktu yang lebih pada fase kedua, menyebabkan alokasi (pembagian) waktu yang telah direncanakan untuk fase-fase selanjutnya menjadi tidak teratur lagi. Dampak dari alokasi waktu yang tidak tepat ini adalah peneliti kurang efektif dalam "Mengendalikan Diskusi" fase ketiga. Sehingga pada saat diskusi tidak semua siswa dapat mengemukakan pendapatnya. Apabila waktu diperhatikan secara efesien maka seluruh siswa dapat melontarkan pertanyaan dan mengemukakan pendapatnya pada proses diskusi.

\section{KESIMPULAN DAN SARAN Kesimpulan}

Berdasarkan data hasil penelitian yang diperoleh dan analisis data serta pengujian hipotesis maka dapat disimpulkan bahwa hasil belajar fisika siswa kelas eksperimen lebih baik dari kelas kontrol. Hal ini dapat dilihat dari rata-rata hasil pretes siswa kelas eksperimen 44,33, sedangkan kelas kontrol 40,33. Seteleh diberikan perlakuan dengan model pembelajaran diskusi kelas dengan metode seminar Socrates pada kelas eksperimen dan 
pembelajaran konvensional pada kelas kontrol maka diperoleh perbedaan hasil belajar siswa pada kedua kelas, yaitu nilai rata-rata postes kelas eksperimen sebesar 70,17 sedangkan kelas kontrol 56,50. Melalui uji hipotesis untuk postes menggunakan uji t diperoleh $t_{\text {hitung }}>$ $t_{\text {tabel yaitu }} 4,79>1,982$.

Kemudian nilai rata-rata aktivitas belajar siswa kelas eksperimen lebih tinggi daripada kelas kontrol di setiap pertemuan. Kelas eksperimen dengan kategori aktif dan kelas kontrol dengan kategori kurang aktif, Hal ini dapat diindikasikan terdapat pengaruh akibat pengaruh model pembelajaran diskusi kelas dengan metode seminar Socrates terhadap hasil belajar siswa.

\section{Saran}

Berdasarkan hasil dan kesimpulan dalam penelitian ini, maka peneliti mempunyai beberapa saran, yaitu: bagi peneliti selanjutnya, hendaknya lebih memperhatikan waktu setiap fasenya agar waktu menjadi efektif dan efesien, sehingga kegiatan pembelajaran berjalan sesuai dengan alokasi waktu yang telah ditentukan dan tiap siswa berkesempatan untuk mengemukakan pendapatnya.

\section{DAFTAR PUSTAKA}

Arends, R. I., (2008), Learning To Teach Edisi Ketujuh Buku Dua, Penerbit Pustaka Pelajar, Yogyakarta.

Permendikbud, (2013), Salinan Permendikbud RI Nomor 69 Tahun 2013, Mendikbud, Jakarta.
Sani, R.A., (2013), Inovasi Pembelajaran, Penerbit Bumi Aksara, Jakarta.

Sudjana, (2005) Metoda Statistika, Tarsito, Bandung.

Sugiyono, (2010), Metode Penelitian Pendidikan, Alfabeta,Bandung.

Trianto, (2011), Mendesain Model Pembelajaran InovatifProgresif, Prenada Media Group, Jakarta

UNDP, (2012), (diakses Desember 2013)

http://hdr.undp.org/en/stati stics/ 